\title{
O misaonoj formi filozofije Josefa Piepera
}

\author{
IVICA RAGUŽ* \\ UDK: 1 Pieper, J. (043.3) • Izvorni znanstveni rad \\ Primljeno: 16. svibnja 2017. • Prihvaćeno: 4. rujna 2017.
}

Sažetak: Članak predstavlja i analizira najvažnije odrednice misaone forme ( $\gg$ Denkform «) Josefa Piepera. U prvome dijelu članka istražuje se utjecaj misli Romana Guardinija na razvoj Pieperove misaone forme. Posebno se zaustavlja kod Guardinijeva predavanja o klasičnom duhu koje je Pieper imao prilike slušati i koje je na njega ostavilo dubok dojam. Takvo shvaćanje klasičnoga duha čini, uz utjecaj fenomenologijske misli, osnovno obilježje Pieperove misaone forme. Klasični duh, kao misaona forma, ovdje znači inzistiranje na objektivnom, na motrenju onoga što nam se daje, onako kako nam se daje. U drugome dijelu članka nastoji se opširnije predstaviti, na temelju nekih tekstova njemackoga autora, teza o klasičnom duhu kao misaonoj formi Josefa Piepera. Treći dio članka

${ }^{*}$ Izv. prof. dr. sc. Ivica Raguž, Katolički bogoslovni fakultet $\mathrm{u}$ Đakovu Sveučilišta J.J.

Strossmayera u Osijeku, P. Preradovića 17, 31400 Đakovo, Hrvatska, ivica.raguz@ os.t-com.hr pokazuje i analizira Pieperovo shvaćanje filozofije, dokolice i mitova koje on, na tragu Guardinija i fenomenologijskoga pristupa, određuje unutar ideje klasičnoga duha. Četvrti dio kritički je osvrt na Pieperovu misaonu formu. Ovdje se izostanak problematiziranja praktičnoga uma (djelovanja) vidi kao osnovni nedostatak iste. Unatoč tomu, ističe se velika važnost $i$ aktualnost misli Josefa Piepera, posebice u vremenu sveopćega subjektivizma, koje je nesposobno za slobodno, nenametlivo motrenje objekta, svega onoga što je dano.

Ključne riječi: Josef Pieper, Romano Guardini, misaona forma, klasični duh, praktični um, djelovanje.

\section{Uvod}

U ovom članku namjera nam je pozabaviti se misaonom formom (Denkform) filozofske i teološke misli njemačkoga filozofa Josefa Piepera. Pod misaonom formom po- 
drazumijevamo središnji, ključni stav, ono što su skolastici nazivali »formalnim objektom «, a što je Hans Urs von Balthasar shvaćao kao »posljednji stav« (letzte Haltung) određenoga mislioca. ${ }^{1}$ Podrazumijeva se da ovdje ovoj temi nećemo pristupiti iscrpno i sveobuhvatno, ukazat ćemo samo na ono što nam se čini najbitnijim za razumijevanje misaone forme filozofije Josefa Piepera.

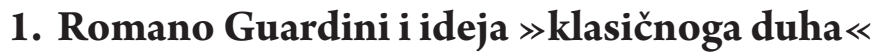

Najveći utjecaj na Piepera ostavio je Romano Guardini. Riječ je o, kako on sam svjedoči, Guardinijevu poimanju klasičnoga duha. Naime, u kolovozu 1924. godine Guardini je održao nekoliko predavanja, a jedno je bilo posebno znakovito i duboko se dojmilo Piepera. Riječ je o Guardinijevu promišljanju klasičnoga duha, posebice Goethea i Tome Akvinskoga. Za pretpostaviti je da je Guardini tim predavanjem htio odati priznanje Goetheu prilikom 175. obljetnice njegova rođenja. Ovako Pieper opisuje doživljaj toga predavanja: »Upravo u tom trenutku dogodilo mi se da su se misaoni materijali, koje sam osjećao da nadolaze u gustoj šumi mučnih mozganja prema svojemu uobličenju, odjednom kao pod čarobnim štapićem sabrali u kristalno obličje. Jednim pogledom mogao sam sve ono što mi je bilo tako zamršeno izraziti jasnim riječima: svako trebanje počiva na bitku; dobro je ono što je u skladu sa zbiljom. Stoga tko želi znati i činiti dobro, taj mora svoj pogled usmjeriti prema objektivnom svijetu postojanja, ne prema vlastitom 'uvjerenju', ne prema 'savjesti', ne prema 'kreposti', ne prema 'idealima', koje sami svojom moći stavljamo, i ne prema 'uzorima'. On mora odvratiti pogled od svojega vlastitoga čina i gledati zbilju. $\ll^{2}$ Pieper je ovu misao zapisao u svojim osobnim bilješkama i one nam daju naslutiti da se upravo u tom Guardinijevu shvaćanju klasičnoga duha krije temeljna misaona forma Pieperove misli. Pogledajmo ukratko kako Guardini shvaća klasični duh.

Riječ je o neobično kratkom promišljanju pod naslovom »O Goetheu, Tomi Akvinskom i o klasičnom duhu «. Kratko je to promišljanje, ali uz zasigurno snažne misli kojima je i sam Guardini izrekao jednu od temeljnih vodilja same svoje teološke misli. ${ }^{3}$ Za Guardinija klasični duh podrazumijeva sljedeće. Kao prvo, klasični duh zahtijeva takav pogled na svijet koji pušta da svaka stvar bude što ona jest. Riječ

\footnotetext{
${ }^{1}$ Svoju metodu interpretacije, tj. razotkrivanja »posljednjega stava « velikih mislilaca, Balthasar je prvi put predstavio u svojem djelu Apokalypse der deutschen Seele (I-III, Johannes, Einsiedeln, 1998.), a potom u svojim mnogobrojnim monografijama posvećenim raznim misliocima (npr. Georges Bernanos, Romano Guardini, Martin Buber i mnogi drugi).

2 J. PIEPER, Noch wußte es niemand. Autobiographische Aufzeichnungen 1904-1945, München, 1976., 70.

${ }^{3}$ R. GUARDINI, Von Goethe, und Thomas von Aquin, und vom klassischen Geist, u: ISTI, In Spiel und Gleichnis, Mainz, 1932., 21.-26.
} 
je o $\gg$ otvorenom pogledu, koji zapravo nikada ne 'želi' nešto, da ta stvar bude takva, neka druga nešto drugo, a treća da uopće ne bude. Taj pogled ne nanosi nasilje nijednoj stvari. $\ll^{4}$ Drugo, takav nenasilni pogled na svijet jest djetinji stav prema cijeloj zbilji, djetinji stav koji podrazumijeva »opušteno povjerenje u bitak, strahopoštovanje spram njegova dostojanstva te širinu, koja svemu daje prostora $\ll^{5}$ Treće, to je stav koji u svakoj stvari zapaža njezinu posebnost upravo zato što joj dopušta da bude takva kakva jest. U klasičnom duhu nema miješanja, stvaranja zamućenoga jedinstva. Klasični duh podnosi razlike, odmake, suprotnost. Stoga klasični duh donosi pred čovjeka $\gg$ živo jedinstvo $\ll^{6}$. Četvrto i najvažnije, klasični duh njeguje stav strahopoštovanja spram svih stvari, daje se voditi onim objektivnim poretkom koji djeluju u njemu samome. Iz toga slijedi da čovjek klasičnoga duha nikad ne polazi od sebe, nego od drugoga, od samoga bitka. Njegov je najdublji stav strahopoštovanje i poslušnost. Poslušajmo središnje Guardinijeve misli: »Možda bi se moglo reći da je u konačnici to stav koji proizlazi iz bitka, stav koji potvrđuje primat logosa spram etosa, $\mathrm{k}$ tomu, primat bitka pred činjenjem. Najdublja bit toga stava nije smionost ili tragično junaštvo, nego strahopoštovanje spram nutarnjega poretka stvari, poslušnost spram odlučujućega Stvoriteljeva poziva u bitku onoga što je on sam stvorio, unatoč svakoj smetnji zbog grijeha. $\ll^{7}$ Klasična misao jest, dakle, misao koja pušta da se stvari same od sebe razvijaju, čovjek se ne nameće svojim vrijednosnim prosudbama, zahtjevima ili nasilnim nametanjima.

Guardini ističe i druge kvalitete klasičnoga duha. To su ponajprije dubina, i to ne dubina tmine, nego dubina velike jasnoće, jasnoće koja u čovjeku izaziva začuđenost, bojazan i zadivljenost. Drugo svojstvo jest jednostavnost. Klasični duh ne traži izvanredne događaje i stvari, nego svakidašnjicu, ali u svakidašnjim događanjima zna primijetiti stvarnosti koje u sebi nose golemo značenje. Zbog te jednostavnosti način klasičnoga mišljenja često se prečuje, čini se da ne kazuje ništa posebno, ali je to zapravo $\gg$ samorazumljivost svjetla koje sve rasvjetljuje gdje god se pojavi. $\ll^{8} \mathrm{Na}-$ posljetku, klasični način mišljenja podrazumijeva odreknuće, odreknuće od svega beskrajnoga, neurednoga, divljega, zapetljanoga, svega onoga što poništava mjeru i formu. Zaključno, piše Guardini, klasični duh jest duh lakoće. On »ono što je teško čini laganim, a da mu pritom ne oduzima njegovu ozbiljnost i njegovu slavu; klasič-

\footnotetext{
${ }^{4}$ Isto, 22.

${ }^{5}$ Isto.

${ }^{6}$ Isto, 23. U pozadini je i Guardinijevo poimanje životnosti kao Gegensatz, kao napetost suprotnosti, oprečnosti. Više o tome vidi u: I. RAGUŽ, Kršćanski - katolički svjetonazor prema Romanu Guardiniju, u: ISTI, Teološki fragmenti I., Đakovo, 2016., 242.-258., posebno 252.-258.

${ }^{7}$ R. GUARDINI, Von Goethe, und Thomas von Aquin, und vom klassischen Geist, 23s.

${ }^{8}$ Isto, 25.
} 
no omogućuje onomu što je bremenito da slobodno stoji, a onomu što posrće da lagano lebdi. Prevladavanje težine i snagu za igru. ${ }^{9}$

Prije nego pokažemo kako se takvo poimanje klasičnoga susreće u Josefa Piepera, potrebno je reći da se i Guardinijeva misao treba smjestiti u ono duhovno ozračje europske kulture koje se pojavilo koncem 1 . svjetskog rata, a to je povratak objektu, objektivnoj misli. U tom smislu Guardini samo izriče ono što je namjera mnogih mislilaca toga vremena, a to je prevladavanje subjektivizma, pragmatizma i naturalizma u filozofiji i teologiji. Riječ je o razočaranju jedne cijele generacije činjenicom da se u cijelosti urušio europski optimizam što se tiče ljudskoga razuma, optimizam povjerenja u ovaj svijet, svijet koji je nudio blaženstvo neposredne spoznaje jasnih ideja (idealizam) ili pak neposredne spoznaje vječnih iskona (romantizam). Da nešto nije u redu s takvim svjetonazorom, dokaz je bila činjenica neviđenoga masakra milijuna ljudi koji je nastao upravo u krilu takve europske misli. Zato za mlađu generaciju mislilaca nakon 1 . svjetskog rata, svijet prestaje biti mjerilo mišljenja i djelovanja, pokušava se učiniti odmak od svijeta, bilo u filozofiji bilo u teologiji. Mnogi su mislioci osjetili da je potreban radikalan zaokret od misli koja je i dovela do katastrofe 1 . svjetskoga rata. $U$ tom smislu treba razumjeti namjeru mnogih mislilaca da se okrenu objektu, objektivnoj misli. Tu treba posebno spomenuti fenomenologijsku misao Edmunda Husserla, kao i Maxa Schelera, koji su ostavili veliki utjecaj na Guardinija i na Piepera.

Tako je namjera Edmunda Husserla i njegove fenomenologijske metode prevladavanje logičkoga subjektivizma. Svijest se sada ne shvaća više funkcionalno, nego intencionalno. Ona je uvijek svijest $\gg$ nečega «, odnosno ona je određena objektom. Sadržaji su svijesti istiniti neovisno o subjektu, cogito je određen s cogitatum, noesis se određuje prema noema. U tom smislu svijest nije ta koja određuje objekt, nego koja se određuje objektom. Uloga fenomenologije jest puštanje da se fenomeni sami izriču u svojoj objektivnosti, u svojem objektivnom logosu. Prvotni čin, kao i kod Guardinija, nije vladanje fenomenima, određivanje fenomena, nego puštanje da se fenomeni očituju u sebi samima. Istinska filozofija krije se u tome gledanju, $u \gg$ evidenciji « $\gg$ zora biti $\ll$. Fenomeni se ne mogu i ne smiju smjestiti u sustave (hegelijanizam), ali ni u neke povijesne općenite forme (historizam), a još se manje smiju reducirati na prirodoslovno-znanstvene zaključke. Tako Husserl želi fenomenima ponovno vratiti njihovo vlastito dostojanstvo, omogućiti im njihovu puninu, njihovo bogatstvo, njihovu »zasićenost « (J.-L. Marion) da dođe do izražaja njihova izvornost, onkraj svih pokušaja reduciranja istih na sisteme ili nekakve a priori.

${ }^{9}$ Isto, 26. 
Slična je situacija i u misli Maxa Schelera, da navedemo još jednoga mislioca koji je zasigurno utjecao i na Josefa Piepera. Schelerov se pak objektivizam ostvaruje na praktičnoj razini. Izvorište dobra nije subjektivna volja, nego je volja dobra samo u onoj mjeri u kojoj opaža objektivne vrednote. Stoga temeljni stav nije kritičko zatvaranje dominantnoga subjekta, nego povjerljivo otvaranje u ljubavi čovjeka koji prima i koji služi. Upravo se ta Schelerova misao može primijetiti i kod Guardinija kao i drugih teologa, gdje su u središtu sljedeće značajke: odmak od jednostranoga bavljenja subjektivnim životom vjere prema bavljenju objektivnom vjerom (dogma), odmak od subjektivnoga kršćanstva duše prema objektivnom kršćanstvu Crkve (Guardini: »Buđenje Crkve u dušama «) te odmak od jednostrane brige za subjektivno spasenje prema predanosti objektivnom služenju (liturgija). Ne ulazeći u detalje, zasigurno se može reći da je Josef Pieper prihvatio misaonu formu klasičnoga duha o kojem je pisao Romano Guardini. Ali Pieper je preuzeo i važnost objekta, objektivne misli koju je zastupala cjelokupna fenomenologijska škola. Dakle, naglasak je na objektivnome, a subjekt je shvaćen kao primalački, u stavu primanja, slušanja, poslušnosti. Sad ćemo to pokazati na primjeru nekih tekstova samoga Josefa Piepera.

\section{Klasičan duh kao Pieperova misaona forma}

Upravo takva i druga svojstva klasičnoga duha provlače se kroz sva djela Josefa Piepera i čine ga nesuvremenim misliocem, kako to piše Hans Urs von Balthasar. ${ }^{10}$ Dok suvremena misao, na tragu Descartesa i Bacona, shvaća znanje kao moć nad zbiljom, a teoriju mjeri praksom proizvodnje, za Piepera je znanje izričaj poniznosti i poslušnosti. Misao koja se neprestano provlači kroz sva Pieperova djela jest naglasak na prvenstvu zbilje, na prvenstvu objekta spram subjekta. U njegovim djelima neprestano susrećemo važnost zamjećivanja zbilje. Pieper upozorava da je na prvom mjestu uvijek spoznaja zbilje, određenost zbiljom. Uvijek treba zbilji, objektu davati prednost, pri čemu čovjek sebe treba ostaviti po strani, u skladu s gore spomenutom Guardinijevom idejom klasičnoga duha. Koliko je Goethe važan Pieperu, svjedoči i to da je objavio kratku zbirku Goetheovih misli, gdje se može pronaći i sljedeća Goetheova misao koja savršeno sažima klasični duh, kao i Pieperovu misaonu formu: »Po mogućnosti sebe što više zanijekati, a objekt tako čisto, koliko god se to može učiniti, u sebe primiti. ${ }^{11}$ Također, na jednom drugom mjestu, on ovako zapisuje kao preporuku maturantima, a koja nam isto pruža uvid u njegov način mišljenja: »Ono što ponajprije želim jednom mladom čovjeku u našem vremenu jest sljedeće: da unutar optičke i akustičke buke ispraznih nadra-

\footnotetext{
${ }^{10}$ H. U. von BALTHASAR, Vorwort, u: J. PIEPER, Lesebuch, München, 1981., 5.-9.

${ }^{11}$ J. PIEPER, Über das Schweigen Goethes, München, 1951., 40.
} 
žujućih stvari poželi očuvati otmjenost šutljivoga slušanja istinskoga zbiljskoga. $\ll^{12}$ Dakle, naglasak je u Piepera uvijek na bitku, na spoznaji bitka, a tek onda na djelovanju. Potrebno je, dakle, na neki način pustiti da bitak djeluje na nama pa da onda, spoznati bitkom, i sami djelujemo. Tako on citira Meistera Eckharta: »Ljudi ne trebaju puno o tome razmišljati što bi trebali činiti. Trebaju razmišljati o tome što trebaju biti. $\ll{ }^{13} \mathrm{U}$ središtu je dakle zbilja, spoznaja cjelokupne zbilje, a onda time i spoznaja pravoga bitka čovjeka, bitka dobroga čovjeka. Iz toga proizlazi da je prvotni čovjekov stav pasivnost, a ne aktivnost; prvo je dati se određivati bitkom, zbiljom, a ne određivati bitak, zbilju. Dakako, kako ističe Pieper, ta pasivnost, koja podrazumijeva zahvaćenost objektom, podrazumijeva golemu aktivnost volje. No, ta volja nema ulogu ovladavanja objektom, nego ona pušta da objekt njome ovlada: »Nevjerojatna se aktivnost volje traži da se u spoznaji dopustimo određivati jedino stvarnošću, da budemo objektivni i istinski, da se silimo na šutnju, na nevidljivost, a time na sposobnost zamjećivanja. $\ll{ }^{14}$

Pieperu je posebno važan Toma Akvinski. On je za njega primjer mislioca objektivne misli o kojoj je bilo govora. Tako njemački filozof navodi Tominu misao da bitak u strogom smislu riječi nije u čovjekovu posjedu, nego da mu pripada kao zajam. ${ }^{15}$ Time se podrazumijeva da čovjek nije gospodar bitka, da on bitak može razumjeti samo tako da se zahvati tim istim bitkom. Čovjek istinito živi jedino ako se dopusti mjeriti objektivnom zbiljom. Pieper tu ne misli samo na teoriju nego i na praksu. Praksa nije ništa drugo negoli $\gg$ čisto zamjećivanje zbilje $\ll .{ }^{16} \mathrm{Ne}$ treba ni čuditi da Pieper ovdje opet spominje Goethea: »'U činjenju i djelovanju najvažnije je da objekte čisto shvatimo i s njima postupamo prema njihovoj naravi.'« Pieper nastavlja: »Praksa počiva na okretu prema zbilji, koji cilja na zamjećivanje realnosti, tj. na istinu i ništa drugo. Drugim riječima: teorija je plodna za praksu samo dok se ne brine da postoji. $\ll{ }^{17}$ Stoga je za Piepera najveći oblik moćnosti nad svijetom spoznaja zbilje. ${ }^{18}$ Jedino tako, što je ovdje posebno važno istaknuti, filozofija, a time i teologija mogu, prema njemačkom filozofu, prevladati opasnost moraliziranja. Naime, moraliziranje je govor o moralu neovisno o spoznaji bitka. Moraliziranje

\footnotetext{
${ }^{12}$ J. PIEPER, Notizen I, u: ISTI, Weistum - Dichtung - Sakrament. Aufsätze und Notizen, München, 1954., 177.

${ }^{13}$ J. PIEPER, Über das christliche Menschenbild, Leipzig, 1940., 10.

${ }^{14}$ J. PIEPER, Die Wirklichkeit und das Gute, München, 1956., 40.

${ }^{15}$ J. PIEPER, Das Geheimnis und die Philosophie, u: ISTI, Weistum - Dichtung - Sakrament. Aufsätze und Notizen, 61.

${ }^{16}$ J. PIEPER, Was heißt akademisch? Oder der Funktionär und der Sophist, München, 1952., 71.

${ }^{17}$ J. PIEPER, Philosophie und Gemeinwohl, u: ISTI, Weistum - Dichtung - Sakrament, 78.

${ }^{18}$ Isto, 82.
} 
izolira činjenje, obavljanje, vježbanje te osamostaljuje cjelokupno moralno djelovanje spram životnoga postojanja živoga čovjeka. Zato je krepost ono što jest, ultimum potentiae, krajnja sposobnost čovjeka kao takvoga, a ne nešto njemu strano. Tako se dobiva dojam da moralnost nema veze sa stvarnošću, da je ona naprotiv suprotna stvarnosti. ${ }^{19}$ Zato za Piepera govoru o krepostima uvijek treba prethoditi promišljanje o bitku. Njemački filozof slijedi skolastički aksiom esse sequitur agere, prvo dolazi esse pa tek onda slijedi agere: $\gg$ Stvarnost je temelj dobroga, što bi ovdje prema značenju 'stvarno - realis' trebalo imati sljedeći smisao: biti dobar znači biti u skladu s objektivnim bitkom; dobro je ono što odgovara 'stvari'; dobro je ono što je sukladno s objektivnom stvarnošću. ${ }^{20}$ Isto se može pronaći u njegovu razumijevanju kreposti, primjerice, kada piše o razboritosti kršćanina: »Kršćanin je razborit, tj. on ne zamućuje pogled na stvarnost ovisno o 'da' ili 'ne' volje, nego 'da' ili 'ne' volje čini ovisnim o istini stvarnih stvari. $\ll{ }^{21}$ To vrijedi i za mudrost, kao i za ostale kreposti: »Mudar je čovjek kada mu sve stvari prijaju kakve one stvarno jesu. $\ll^{22}$

To sve Pieper pronalazi kod Tome Akvinskoga, kojega on, po uzoru na Romana Guardinija, a uz Goethea, uzima za uzor svoje misaone forme. Prema Pieperu, sam život sv. Tome kazuje da je u središtu istina stvari, pravičnost: »On je sam uvijek iznova govorio da se savršenost života više sastoji od nutarnjeg bivanja pravednim nego od izvanjskih činova askeze. ${ }^{23}$ Nadalje, budući da je jedino Božja stvaralačka spoznaja mjerodavna, a ne mjeroprimljiva (mensurans non mensuratam), čovjekova je spoznaja uvijek mjeroprimljiva, a nikako ne mjerodavna. Upravo se u toj činjenici stvorenja očituje da za Piepera čovjekov prvotni stav spram zbilje nije određivanje, nego primanje. Tu se i, što ovdje samo kratko napominjemo, Pieper razlikuje od Husserla. Kod Husserla krajnja evidencija zora biti ipak na kraju završava u čovjekovoj svijesti. ${ }^{24}$ Kod Piepera pak, koji slijedi Tomu Akvinskoga, ta redukcija na subjekt nije moguća, jer je jedino Bog krajnja mjerodavna stvarnost svih stvari i svih fenomena. Krajnja redukcija nije u čovjekovoj svijesti, nego u Bogu. U tom smislu Pieper s pravom tvrdi da se stvari mogu, prema Tomi Akvinskom, pravo shvatiti samo ako ih shvaćamo kao stvorenja. Naime, činjenica da su stvari stvorenja doziva u svijest da su sve stvari proizašle iz Božje, a ne iz čovjekove spoznaje: »Stvari su za nas spoznatljive po tome što ih je Bog izmislio. Kao od Boga izmišljene stvari

\footnotetext{
${ }^{19} \mathrm{~J}$. PIEPER, Über das christliche Menschenbild, 26s.

${ }^{20}$ J. PIEPER, Die Wirklichkeit und das Gute, 13.

${ }^{21} \mathrm{~J}$. PIEPER, Über das christliche Menschenbild, 14s.

${ }^{22}$ Isto, 28.

${ }^{23}$ J. PIEPER, Hinführung zu Thomas von Aquin, Freiburg, 1967., 25.

${ }^{24} \mathrm{O}$ kritici Husserlove misli s tog gledišta vidi primjerice J.-L. MARION, Étant donné. Essai d’une phénoménologie de la donation, Paris, 1998., 33.-50., posebno 49.-50.
} 
nemaju samo svoju bit (takoreći svoj 'biti za sebe'), nego kao od Boga izmišljene stvari imaju i bitak 'za nas'. « ${ }^{25}$ Time se podrazumijeva da čovjek, kao stvorenje, nikad ne može i ne smije ovladati stvarima, jer one, budući da su od Boga izmišljene, izmiču čovjekovoj krajnjoj spoznaji, redukciji na njegovu svijest. Štoviše, Toma Akvinski, u interpretaciji Josefa Piepera, ide tako daleko da čovjekovu spoznaju smatra učinkom same istine, što se protivi svakoj subjektivizaciji spoznaje i istine. Dakle, čovjekova je spoznaja uvijek sekundarna spram istine stvarnosti, ona je neka vrsta učinka istine stvarnosti nad nama. ${ }^{26}$ Budući da su sve stvari Božja stvorenja, mi nismo u stanju spoznati njihov odnos, njihov adaequatio, podudarnost s Bogom Stvoriteljem, koji je njihov uzrok i prauzorak, a time jedini istinski spoznavatelj. U tom smislu trajna nespoznatljivost svih stvari proizlazi iz činjenice da su sve stvari Bogom stvorene. Nespoznatljivost svih stvari nema veze $s$ nečim tamnim, gdje bi mogao nastati dojam da čovjek tu tamu ipak jednom može do kraja spoznati (racionalizam) ili pak spoznajno prije ili kasnije mora rezignirati pred tom tamom (iracionalnost). Za Piepera nespoznatljivost svih stvari izričaj je činjenice da su sve stvari osvijetljene takvom puninom svjetla, Božjega svjetla, da čovjekova spoznajna mogućnost ne može do kraja obuhvatiti nijednu stvar, svaka stvar izmiče čovjekovoj spoznaji. ${ }^{27}$ Dakako, upravo zato što su stvari Božja stvorenja, čovjek ih može spoznavati, one imaju $\gg$ svoju bitkovitu rasvijetljenost $i$ očitost kao $i$ istodobno svoju neshvatljivost i 'neiscrpljivost', svoju spoznatljivost i svoju 'nespoznatljivost' ${ }^{28}{ }^{28}$ $\gg$ Tko, dakle, filozofirajući pita o biti stvari, taj dospijeva, upravo zato što doseže svoj objekt, u jedan neistraživi ponor, ali je to ponor svjetla. $\ll^{29}$ Stoga je $\gg$ stvarno istinito, ako oslikava prasliku božanskoga spoznavanja $\ll .{ }^{30} \mathrm{U}$ tom smislu kršćanski filozof ne završava s rezignacijom ili očajem spram neistražive stvarnosti, nego sa štovanjem. ${ }^{31}$

Pieperova misaona forma možda najsnažnije dolazi do izražaja u jednom od njegovih vjerojatno i najupečatljivijih promišljanja, koje je Hansa Ursa von Balthasara posebno oduševilo, a to je promišljanje o skromnosti jezika u filozofiji. Pieper je napisao to promišljanje kao pogovor prijevodu djela Clivea Staplesa Lewisa o boli. Pieper postavlja kao tezu: »Budi spor u povjerenju onomu čemu nedostaje

\footnotetext{
${ }^{25}$ J. PIEPER, Unaustrinkbares Licht. Das negative Element in der Weltansicht des Thomas von Aquin, München, 1963., 26.

${ }^{26}$ J. PIEPER, Die Wirklichkeit und das Gute, 56s.

${ }^{27}$ J. PIEPER, Unaustrinkbares Licht, 32.

${ }^{28}$ J. PIEPER, Verteidigungsrede für die Philosophie, 43.

${ }^{29}$ J. PIEPER, Unaustrinkbares Licht, 75.

${ }^{30}$ Isto, 34.

${ }^{31}$ Isto, 95.
} 
skromnost. Ona je pečat vjerodostojnosti. $\ll^{32}$ Čovjek daje povjerenje onomu koji sebe ne nameće, koji ništa ne želi za sebe. Stoga skromnost govora ukazuje na činjenicu da je osoba krajnje posvećena ne sebi, nego stvari, objektu. Zato je, piše Pieper, Goethe radije davao prednost $\gg$ manje značajnom pojmu « kako bi jasnije došle do izražaja same stvari, njihova bit: »Tko voli sebe stavljati u središte lažnom pompom dikcije, njemu upravo zbog toga nedostaje pogled na jasnoću prave skromnosti. ${ }^{33}$ Druga pak teza glasi: »Riječ odrasloga ljudskog jezika izriče više realnosti nego umjetni termin. ${ }^{34}$ Termin, stručni naziv, koristi se radi preciznog razumijevanja određenoga objekta. Termin, tvrdi Pieper, kirurški odvaja određeni objekt od drugih objekata. No, u stvarnosti to nije tako, u stvarnosti su svi objekti uzajamno povezani, nijedna stvar nije izolirano razgraničena od druge. Zato filozof motri svaku stvar u vezi s drugom, uvijek misli svaku stvar u kontekstu cjelokupne zbilje, zbilje koja ostaje nikad do kraja spoznatljiva. U tom smislu svaka riječ prirodnoga jezika svjedoči o toj nepojmljivosti cijele zbilje, o njezinom golemom bogatstvu koje se nikad do kraja ne može iscrpiti. $U$ tom smislu veliki se mislilac pokazuje upravo u skromnosti i jednostavnosti jezika, jer upravo na taj način uspijeva izreći cjelokupnost zbilje: »Dakle, još jednom, što pisac ostaje bliži prirodnom govoru kojim govori narod, što je njegov jezik skromniji, tim je bogatiji slojevitošću zbilje. ${ }^{35}$ Naposljetku, skromnost jezika govori nešto i o istinskom podučavanju. Budući da je iskonsko mjesto poduke živo podučavanje, susret oči u oči učitelja i učenika, skromnost pisane riječi gotovo da uspijeva staviti pisca i čitatelja u stvarni, živi razgovor: »Najugodnije su one knjige koje čitatelja niti ignoriraju, niti varaju, kod kojih se čitatelj može osjećati kao sudionik mirnoga razgovora među džentlmenima, gdje je štovan 'veselim iskazivanjem počasti', koju je Goethe hvalio. ${ }^{36}$

\section{Pieperovo poimanje filozofije, dokolice, mitova $\mathbf{i} \gg$ klasični duh«}

$\mathrm{U}$ članku znakovitoga naslova $\gg \mathrm{O}$ osluškivanju i filozofijskoj interpretaciji $<\mathrm{Pi}$ eper, na tragu Guardinija i gore spomenute fenomenologijske škole, i samu filozofiju određuje unutar ideje klasičnoga duha, a to znači prvotno kao osluškivanje, kao »stav šutliive spremnosti za primanje, dakle, stav primanja, slušanja i osluškivanja $\ll \cdot{ }^{37}$ Filozofija je negativna znanost, znanost koja više pita negoli daje

\footnotetext{
${ }^{32}$ Über die Schlichtheit der Sprache in der Philosophie, u: ISTI, Tradition als Herausforderung, 287.

${ }^{33}$ Isto, 288.

${ }^{34}$ Isto, 289.

${ }^{35}$ Isto, 291.

${ }^{36}$ Isto, 293.

${ }^{37}$ J. PIEPER, Über das Zuhören und die philosophierende Interpretation, u: ISTI, Weistum - Dichtung - Sakrament, 13.
} 
odgovore. Ona se ne da reducirati na određeni $\gg$ fah $\ll$, nego se odnosi na cjelinu svijeta, na cjelinu mudrosti. ${ }^{38}$ Filozofa uopće ne zanima filozofija kao takva, nego istina samih stvari, cjelina svijeta i čovjeka. ${ }^{39}$ Dakako, ta je cjelina zbilje neistraživa te filozof može cijeloj toj zbilji pristupati jedino na način učenoga neznanja. Stoga filozofija, za razliku od ostalih znanosti, ne završava, nego započinje na granici znanja. ${ }^{40}$ Ključan stav filozofije jest otvorenost za ono što izaziva divljenje, stav gdje se duša dopušta pogoditi drugošću zbilje, gdje se zauzima stav jednostavnosti koji omogućuje da objekt filozofiranja dođe u pogled. ${ }^{41}$ Dakle, u središtu filozofiranja nije vladajući, nego služeći subjekt: »U filozofiranju ne nastupa suvereno planirajući um nasuprot svijetu 'mogućih objekata', kojima se on tada, ovisno o različitim svrhovitostima, slobodno obraća. Filozofiranje pak ishodi iz nedostatnoga, čega nismo Gospodari, nego što naprotiv iznad naših glava zahtijeva smirivanje. $\ll{ }^{42}$ Zato filozofija ne može uspijevati tamo gdje čovjekom vladaju interesi, tamo gdje čovjek nije sposoban napustiti svoj ego i dati se zahvatiti bitkom, zbiljom: »Gdje uvijek ovladava 'sebeljublje' prostorom postojanja, tamo se ne može očekivati da će filozofijski čin uspijevati, ako se uopće i ostvari. ${ }^{43}$ Zato filozof filozofira ne imajući na umu nikakvu svrhu, nikakvu korist, interes. ${ }^{44}$

Jedino takva filozofija omogućuje pravu interpretaciju velikih filozofa, primjerice Platona i Tome Akvinskoga. U suprotnom se interpretacija velikih filozofa reducira na historizam, gdje se djela i autore tumači isključivo u kontekstu određenoga povijesnoga vremena, gdje se minuciozno tumače mnogobrojni detalji istoga djela, ali se pritom promašuje stvarna tema onoga što određeni autori promišljaju. Razlog je taj što nema osluškivanja u tom stavu, jer osluškivanje podrazumijeva zahvaćenost objektom istraživanja, i to tako, kako ispravno primjećuje Pieper na tragu Tome Akvinskoga, da se sam tumač bavi istim pitanjima, odnosno da misli ne samo ono što su drugi mislili, nego da sam misli istinu stvari. Dakle, nije dostatno samo razumjeti ono što su drugi mislili, nego je potrebno tumačiti iste mislioce promišljajući istu stvarnost s gledišta veritas rerum, »istine stvari «. ${ }^{45}$ To je jedino

${ }^{38}$ J. PIEPER, Philosophie - Kontemplation - Weisheit, Einsiedeln - Freiburg, 1991., 27.

${ }^{39}$ J. PIEPER, Hinführung zu Thomas von Aquin, 133.

${ }^{40}$ J. PIEPER; Philosophie - Kontemplation - Weisheit, 37.

${ }^{41}$ Isto, 40.

${ }^{42}$ Isto, 45.

${ }^{43}$ J. PIEPER, Verteidigungsrede für die Philosophie, München, 1966., 43.

${ }^{44}$ Opširnije o tome te Pieperovu poimanju sveučilišta vidi u: I. RAGUŽ, O »teoriji i sveučilištu nekoć i danas, u: Diacovensia 19(2011.)3, 383.-391.

${ }^{45}$ J. PIEPER, Über das Zuhören und die philosophierende Interpretation, 20. Ista misao u: Billigkeit in der Interpretation, u: ISTI, Tradition als Herausfordrung, 244s. Također ISTI, Hinführung zu Thomas von Aquin, 53. 
ispravno filozofijsko tumačenje, koje se razlikuje od historijskoga. Dakako, Pieper time ne želi omalovažiti važnost historijskoga tumačenja djela, nego samo ukazati na ono što je posebnost filozofijske interpretacije. Ovako to sažima Pieper: »Veliki autor, prije svega ako je udaljen vremenskim odmakom ili kulturalnom drugošću, može za čitatelja postati živi duhovni lik iznad pukoga historijskoga i muzejskoga, a njegov nauk, njegova poruka bit će istinski prepoznata i uporabljiva, ako se ono što je on rekao i mislio stavi u vezu i konfrontira s onim što sami smatramo istinom. ${ }^{46}$ U skladu s našom temom i ovdje se može primijetiti da je u Pieperovu poimanju filozofijske interpretacije ponovno u središtu klasični duh, tj. stav osluškivanja, zahvaćenosti, bilo objektom istraživanja bilo samom »istinom stvari«.

Klasični duh dolazi do izražaja i u Pieperovu tumačenju Platonove manije. Manija za Piepera predstavlja božansku ludost, potpunu zahvaćenost božanskim, oduzetost i potresenost objektom, odnosno božanskim. Ona podrazumijeva biti izvan sebe, gubitak vlasti nad samim sobom, gubitak autarkičnoga samoposjedovanja i samokontrole. To je stanje u kojemu smo pasivni, a ne aktivni. ${ }^{47}$ To znači da se čovjek ne ostvaruje jedino tako što sebe posjeduje i sebe određuje u slobodi, tako što kritički pristupa svim stvarima i oblikuje ih svojom spoznajom i djelovanjem. U Pieperovu tumačenju Platonove manije čovjek se očituje i kao biće kojemu se nešto tako veliko može dogoditi, kojega nešto tako veliko može pogoditi da bude doslovno izbačen iz svojega sebeposjedovanja te mu upravo tako, odnosno jedino tako, biva darovano nešto veliko koje mu se jedino na taj način, način manije, gubitka samoposjedovanja, i može dati. Pieper citira Hölderlina: »Veliko je pomagalo skrovito radinoj duši da ona na najvišoj svijesti izmiče svijesti. $\ll{ }^{48}$ Drugim riječima, stvaralaštvo podrazumijeva golemu aktivnost, svijest kao samoposjedovanje, ali istodobno i napuštanje, izmicanje toj istoj svijesti u sebegubljenju, u maniji.

Nadalje, za Piepera čovjekova se sloboda temelji na spoznaji, spoznaji ponovno shvaćenoj kao zor zbilje, ako je on usmjeren na samu istinu stvari. Istina stvari čovjeka čini slobodnim. ${ }^{49} \mathrm{I}$ cjelokupna znanost počiva na teorijskom poimanju zbilje, gdje se zbilji pristupa isključivo $s$ teorijskog gledišta, dakle, na način šutljivoga slušanja istine onkraj svakoga pitanja praktičnosti i realizacije određenih svrha. Tako filozof, prije svega, ne traži sigurnost spoznaje, nego samu zbilju; ne zanima ga odnos prema svijetu, nego sam svijet. ${ }^{50}$ On u svojem promišljanju ne traži apsolutnu

\footnotetext{
${ }^{46}$ J. PIEPER, Begeisterung und göttlicher Wahnsinn, München, 1962., 147.

${ }^{47}$ Isto, 84 .

${ }^{48}$ Isto, 109.

${ }^{49}$ J. PIEPER, Erkenntnis und Freiheit, u: ISTI, Weistum - Dichtung - Sakrament, 34.

${ }^{50}$ J. PIEPER, Über das Verlangen nach Gewissheit, u: ISTI, Weistum - Dichtung - Sakrament, 44. Također, Philosophie und Gemeinwohl, u: ISTI, Weistum - Dichtung - Sakrament, 75.
} 
sigurnost. Naprotiv, želja je za apsolutnom sigurnošću nijekanje onog temeljnog filozofijskog stava, a to je osluškivanje, primanje. ${ }^{51}$

U tom kontekstu Pieper razumijeva i Platonove mitove. Mitovi su u Pieperovoj interpretaciji Platona izričaji onih događanja koja se ne mogu izreći nikako drukčije nego simboličkim govorom. U tom smislu mitovi nisu nekakav deficijentan način govora ili mišljenja koji se može i treba ukinuti u pojmovima, nego su oni izričaji činjenice da se određena događanja ne mogu nikako drukčije izreći osim mitski. ${ }^{52}$ Mitovi također podrazumijevaju tradiciju, primanje određene pripovijesti slušanjem, ex akoés. U tom slušanju veliku ulogu imaju »stari«, osobe koje Platon ne imenuje. To su osobe koje nisu izmislile mit, nego koje su predale ono što su same primile, a to je dar samih bogova. ${ }^{53}$ Dakle, spram mitova čovjek je pozvan zauzeti primalački stav slušanja, jer se mitovi jedino mogu razumjeti slušanjem, ex akoés, dakle ne iskustvom, verificiranjem, nego jedino na način vjerovanja.

Budući da mitovi svjedoče o određenim događanjima koji izmiču čovjekovoj spoznaji, oni se ne mogu i ne smiju svesti na opće razumske pojmove. Mitska se istina ne može izvesti iz apstraktnih principa, jer se ona temelji na »događajima i djelatnostima koje izviru iz slobode, iz Božje i čovjekove slobode. ${ }^{54} \mathrm{U}$ mitovima, u mitskim istinama čovjek biva zahvaćen istinom koja mu je dana i koju može primiti jedino slušanjem te koja se ne može ukinuti i izvesti iz općih razumskih principa. Zato je posebnost kršćanske filozofije upravo u tome što ona uzima u obzir to mitsko, odnosno ono što kršćanstvo naziva povijesnim $\gg$ mitom $\ll$, Božjom objavom u Isusu Kristu. U tom smislu Božja objava pruža filozofijskom mišljenju »plodan otpor «; filozofijsko mišljenje, piše Pieper, »nalikuje pjenušanju duha pri udaru na greben božanske istine $\ll .{ }^{55}$ Dakle, filozofijsko mišljenje ne staje kod objave, nego se tek »pjeni«, započinje, ali uvijek u svijesti da ono nikad ne može dosegnuti, obuhvatiti sadržaj te iste objave. Stoga je »kršćansko filozofiranje kompliciranije, jer ono zabranjuje da poželimo doći do 'shvatljivih' formulacija na način da odvratimo pogled od stvarnosti, da izabiremo, da ispuštamo. Kršćansko filozofiranje, koje je po pogledu na objavljenu istinu premješteno u plodnu uznemirenost, prisiljeno je prostranije misliti, a prije svega se ne zadovoljiti plitkošću racionalističkih harmonizacija. $\ll^{56}$

${ }^{51}$ J. PIEPER, Über das Verlangen nach Gewissheit, u: ISTI, Weistum - Dichtung - Sakrament, 48.

52 J. PIEPER, Über die Platonischen Mythen, München, 1965., $22 \mathrm{s.}$

${ }^{53}$ Isto, 78. Tom se temom Pieper opširnije pozabavio u: Überlieferung. Begriff und Anspruch, München, 1970., 45.-62.

${ }^{54}$ J. PIEPER, Über die Platonischen Mythen, 81.

${ }^{55}$ J. PIEPER, Was heißt Philosophieren? Mit einem Nachwort von T. S. Eliot, München, 1967., 105s.

${ }^{56}$ Isto, 105. 
Odatle treba razumjeti i Pieperovo zanimanje za slavlje i dokolicu. Upravo se u slavlju i dokolici ostvaruje onaj temeljni stav klasičnoga duha, a to je odmak od aktivnoga, vladarskoga stava spram zbilje. ${ }^{57}$ Tako se, primjerice, dokolica protivi precjenjivanju aktivnosti u kojima se ne vjeruje u mogućnost da se nešto dogodi, da se nešto primi. Ona se protivi i precjenjivanju napora i teškoga, gdje se dobro uvijek shvaća kao nešto teško, u čemu Pieper primjećuje nedostatak dara, obdarenosti. Jer, tamo gdje nema dara, tamo je sve dobro shvaćeno kao isključivi izričaj muke i težine. Naposljetku, tvrdi Pieper, živimo u vremenu gdje se svaka djelatnost nužno podređuje $\gg$ socijalnoj funkciji «. Ona je toliko vrijedna koliko je podređena korisnosti određenoga sustava. U tom smislu dokolica je, a onda i slavlje, neaktivna djelatnost, izričaj šutnje kao slušanja zbilje i drugoga. Dokolica je slavlje, a slavlje je suprotnost od muke; dokolica je događaj slobode, jer se čovjek izvodi iz podređenosti socijalnoj funkciji.

To vrijedi i za krepost učenja. Jedan je od glavnih preduvjeta učenja stav slušanja: »Tko želi iskusiti kako stvari stoje s posljednjim, istinskim, s Bogom i sa svijetom, taj se mora nekom čovjeku povjerljivo obratiti, a to znači u izvjesnom smislu nekritički, u šutljivoj spremnosti želje za slušanjem. $\ll^{58} \mathrm{Nema}$, dakle, ni učenja bez onoga stava klasičnoga duha, a to je stav djetinjega duha, nekritičkoga potvrđivanja i prihvaćanja onoga što nam se daje.

\section{Kritički osvrt}

Ne ulazeći u ostale detalje bogate misli njemačkoga filozofa, potrebno je i kratko se kritički osvrnuti na njegovu misao. Ono što nam se čini najvećim nedostatkom njegove misaone forme jest to što Pieper nedovoljno tematizira praktični um, tj. čovjekovo djelovanje. On se uglavnom ograničava na Tomino promišljanje da »praktično spoznavajući duh uzrokuje stvari; tako je on mjera stvari koje po njemu nastaju. Teorijski spoznavajući duh pak prima od stvari, on je u određenom smislu pokrenut tim stvarima te su tako stvari njegova mjera. $\ll{ }^{59}$ Pieper ukazuje na jedinstvo teorijskoga i praktičnoga uma, pri čemu se teorijski um u praktičnom samo proširuje (per extensionem), ako usmjerava spoznatu istinu prema činjenju. Praktični um proizlazi iz teorijskoga, iz spoznaje istine stvari i na temelju te spoznaje donosi odluku i zapovijed s obzirom na djelovanje. ${ }^{60}$ To je zapravo sve što Pieper piše

\footnotetext{
${ }^{57}$ J. PIEPER, Muße und menschliche Existenz, u: Tradition als Herausforderung, München, 1963. 193.-201. Vidi također I. RAGUŽ, Šutnja - dokolica - molitva, Zagreb, 2011., 51.-71.

${ }^{58}$ J. PIEPER, Die Lernenden, u: Tradition als Herausforderung, 276.

${ }^{59}$ J. PIEPER, Wahrheit der Dinge. Eine Untersuchung zur Anthropologie des Hochmittelalters, München, 1947., 39s.

${ }^{60}$ J. PIEPER, Die Wirklichkeit und das Gute, 45.-51.
} 
o praktičnom umu. Dakako, u njegovim traktatima o krepostima susrećemo mnoga promišljanja o čovjekovu djelovanju. Ipak, djelovanje u njega nije tema posebnoga promišljanja. Štoviše, djelovanje je krajnje potisnuto naglaskom na motrenje, što smo već susreli u Guardinijevu poimanju klasičnoga duha. S pravom Pieper ističe prevagu zbilje, objekta spram subjekta, ali se time uloga subjekta reducira na puko motrenje, na slušanje, na poslušnost spram zbilje ili objekta. Uloga je subjekta krajnje minimalizirana, subjekt je promatrač, motritelj, neka vrsta čuvara objektivne zbilje i objektivnih istina. Posebno se to može vidjeti u njegovu poimanju ljubavi, u kojem Pieper pokušava ozbiljnije uzeti u obzir ulogu subjekta. Riječ je o vrlo dubokim i snažnim mislima o ljubavi, ali ju Pieper uopće ne promišlja u kontekstu spoznajne teorije, odnosno unutar odnosa prema zbilji i objektu. Ljubav se reducira na »odobravanje «, » potvrđivanje drugoga «, na prihvaćanje drugoga. ${ }^{61}$ Nigdje nema govora o ljubavi shvaćenoj kao drami izlaženja iz sebe, ljubavi kao sebeponištenju i služenju drugomu, ljubavi kao primanju drugoga. U konačnici, nigdje se ne govori o ljubavi unutar koje se događa razotkrivanje same zbilje, u skladu s mišlju sv. Grgura Velikoga: notitia amor est. U tom smislu ne možemo se oteti dojmu da Pieperova misaona forma ne uspijeva do kraja izbjeći opasnost određenoga objektivizma. Riječ je o takvoj prevazi objekta da subjekt uopće ne dolazi do izražaja.

Međutim, čovjek se ne ostvaruje samo u motrenju nego i u djelovanju. Djelovanje nije samo puki nastavak i posljedica motrenja; praksa nije samo izričaj teorije, nego djelovanje ima svoje zakonitosti koje se ne daju izvesti iz teorije. Mogli bismo reći da je temeljna razlika djelovanja spram motrenja u tome što je djelovanje dijaloška stvarnost. Dakako, u strogo teološkom smislu, i motrenje je dijaloška stvarnost. Dok je filozofija samačko mišljenje, »misleće mišljenje «, u kojem čovjek polazi od sebe, teologija je »mišljenje govora «, mišljenje koje se događa pred Osobom, pred Bogom, mišljenje kao slušanje, mišljenje kao cjelovita predanost Gospodinu. ${ }^{62}$ Ipak, djelovanje je dijaloška stvarnost par excellence. Ono se uvijek događa s drugim i naočigled drugoga. U skladu je to i s biblijskom porukom o činjenju istine: »Tko čini istinu, dolazi k svjetlosti nek bude bjelodano da su djela njegova u Bogu učinjena.« (Iv 3, 21) Time se podrazumijeva da se istina razotkriva tako što ju se čini i djeluje. U tom smislu treba shvaćati ljubav kao zajedničko »činjenje istine «, takvo činjenje gdje se u razgovoru, zajedničkoj predanosti, zajedničkom služenju, istina zbilje razotkriva. Mogli bismo reći da zbilja kao takva ne može cjelovito doći do izražaja bez djelovanja.

I ne samo to. Bez djelovanja ideja je klasičnoga duha u velikoj opasnosti da upadne ne samo u objektivizam nego u određenu taštinu subjekta, gdje se više ne brine do-

\footnotetext{
${ }^{61}$ J. PIEPER, Über die Liebe, Kösel, München, 1972., 38., 80., 180.

${ }^{62}$ F. ROSENZWEIG, Die Schrift. Aufsätze, Übertragungen und Briefe, Frankfurt am Main, 1964., 200.
} 
voljno o razlici između objekta i subjekta. Naime, poslušno i ponizno motrenje zbilje, objekta, daje subjektu određeni smiraj, koji proizlazi iz činjenice da se u njegovu duhu otiskuje sama zbilja, objekt. Taj smiraj subjekta u objektu, dakako, isključuje identitet subjekta i objekta, jer Pieper neprestano upozorava kako su objekti u cijelosti spoznati jedino Bogom, tj. oni izmiču čovjekovoj spoznaji, njihova spoznatljivost obavijena je golemim svjetlom Božje spoznaje koja čovjeku ostaje trajno nespoznatljiva. Ali tamo gdje je subjekt isključivo sveden na miran stav motrenja, subjekt ostaje statičan, ostaje kod sebe. Kako tvrdi Toma Akvinski, spoznaja je uprisutnjavanje objekta u subjektu, odnosno subjektovo posjedovanje samoga objekta. U spoznaji objekt počinje »postojati u našem umu. ${ }^{63}$ Iz toga slijedi da se klasični duh lako može pretvoriti u esteticizam, u spoznajno uživanje istine, u skladno poistovjećenje objekta i subjekta. Djelovanje je pak, a time ljubav, izlaženje subjekta iz sebe prema objektu, motio vitalis, prema Tomi Akvinskom. Ljubav je izlaženje iz sebe, kretanje prema drugome, secundum rationem impellentis et moventis. ${ }^{64}$ Toma Akvinski piše: »Prema tome ono što se ljubi nije samo prisutno u umu bića koje ljubi nego i u njegovoj volji, no drukčije u jednom, a drukčije u drugom. U umu je doista prisutno po sličnosti sa svojom vrstom, dok je u volji ljubećeg prisutno kao dovršetak gibanja u pokretačkom počelu, koje je s podudarnošću i s razmjernošću namješteno prema onome što se ljubi. ${ }^{65}$ Tako u djelovanju čovjek doživljava svoju ograničenost, nedostatnost, stavljen je u nemir traganja, u nemir ovisnosti o drugome. Djelujući čovjek biva lišen opasnosti identiteta subjekta i objekta. Himan Poslanice Filipljanima govori nam o ljubavi kao kenosisu, kao sebeponištenju, kao napuštanju uzvišenosti vlastite forme, forme uzvišenosti te uzimanju forme roba, služenja. (Fil 2, 7-8) Stoga se u djelatnosti ljubavi, u konkretnoj ljubavi kao sebeponištenju i služenju drugomu daje cjelovitija prednost objektu nego u motrenju bez djelovanja. U djelovanju je subjekt deformiran, stavljen u znak križa, kako kaže sv. Augustin. ${ }^{66}$ Subjekt je lišen i posljednje vladavine nad objektom, nad zbiljom.

Naposljetku, ni čovjekova se sreća ne može isključivo shvaćati s gledišta kontemplacije, kako to čini Pieper u svojem djelu $\gg$ Sreća i kontemplacija $\ll{ }^{67} \mathrm{U}$ cijelom tom djelu o sreći se isključivo govori s gledišta motrenja, gotovo da i nema govora o sreći s gledišta zajedništva, kao uživanju u drugome, druženju s drugim, koje nije

\footnotetext{
${ }^{63}$ TOMA AKVINSKI, De veritate, 2, 2; Također Summa theologiae I, q. 27, a. 4.

${ }^{64}$ TOMA AKVINSKI, Summa theologiae I, q. 27, a. 4.

${ }^{65}$ TOMA AKVINSKI, Suma protiv pogana, IV, 19 (prijevod Augustin Pavlović), Zagreb, 1994.

${ }^{66}$ I. RAGUŽ, Bit katolicizma: euharistija, u: Vjesnik Đakovačko-osječke nadbiskupije i Srijemske biskupije 145(2017.)4, 33.-39., posebno 39.

${ }^{67}$ J. PIEPER, Glück und Kontemplation, München, 1979.
} 
samo motrenje nego i djelovanje, služenje u ljubavi, kako smo pokazali. Upravo to Pieperovo djelo pokazuje svu ograničenost njegove misli.

Imajući u vidu ovakvo shvaćanje odnosa objekta i subjekta, ne možemo se oteti dojmu da upravo zbog toga Pieperova misaona forma odiše određenom objektivističkom hladnoćom, u kojoj ne dominira samo objektivno, zbiljsko, nego u kojoj subjekt ostaje pri sebi, statičan, gotovo poistovjećen sa samim objektom. Tako nam se čini da bi njegova misao trebala biti nadopunjena važnošću djelovanja, služenja u ljubavi.

Dakako, u vremenu sveopćega subjektivizma, krajnje nesposobnosti za slobodno, nenametljivo motrenje svega onoga što je dano, gdje su i teologija i filozofija zapostavile onaj iskonski filozofijsko-teologijski stav divljenja prema cjelokupnoj zbilji, Bogu, gdje su se one pretvorile $u \gg z n a n o s t i<$, a time udaljile od same zbilje, Pieperova je misaona forma danas više nego aktualna. Ono što je Hans Urs von Balthasar sažeo kao središte njegove misaone forme, ostaje trajno nadahnuće i za današnju filozofiju i teologiju: »Prihvaćanje i puštanje da dano bude onako kako ono sebe daje, u svojoj istini, dobroti i ljepoti, pretpostavka je da možemo nešto od njega iskusiti. $\ll^{68}$

${ }^{68}$ H. U. von BALTHASAR, Vorwort, 6. 


\title{
ON THE THOUGHT FORM OF JOSEF PIEPER'S PHILOSOPHY
}

\author{
Ivica RAGUŽ*
}

Summary: The article presents and analyzes the most important determinants of Josef Pieper's thought form (»Denkform «). The first part of the paper examines the influence of Romano Guardini's thought on the development of Pieper's thought form. Particular attention is put on Guardini's lecture on the classical spirit which Pieper had an opportunity to hear and which left a deep impression on him. Such an understanding of the classical spirit, together with the influence of the phenomenological thought, is the basic characteristic of Pieper's thought form. The classical spirit, as a thought form, here means the insistence on the objective, on observing what is being given to us, as it is given to us. The second part of the paper seeks to broadly present, based on some texts of the German author, a thesis on the classical spirit as Josef Pieper's thought form. The third part of the article shows and analyzes Pieper's understanding of philosophy, leisure, and myths which he, in line with Guardini and the phenomenological approach, determines within the idea of the classical spirit. Part four is a critical review of Pieper's thought form. Here, the absence of problematization of the practical mind (action) is seen as the basic lack of the same. Nevertheless, there is an emphasis on the great importance and the actuality of Josef Pieper's thought, especially in the age of universal subjectivism, which is incapable of free, unobtrusive observation of the object, of all that is given.

Keywords: Josef Pieper, Romano Guardini, thought form, classical spirit, practical mind, action.

\footnotetext{
*Assoc. Prof. Ivica Raguž, Ph. D., Catholic Faculty of Theology in Đakovo, J. J. Strossmayer University of Osijek, P. Preradovića 17, 31400 Đakovo, Croatia, ivica.raguz@os.t-com.hr
} 